\title{
Effectiveness of health-promoting activities in the area of general hearing screening tests in newborns in Poland
}

\author{
Mira Lisiecka-Biełanowicz ${ }^{1, C-F}{ }^{\oplus}$, Bartłomiej Molenda ${ }^{2, A-D, F} \oplus$ \\ ${ }^{1}$ Department of the Prevention of Environmental Hazards and Allergology, Faculty of Sciences, Medical University of \\ Warsaw, Poland \\ ${ }^{2}$ Department of Public Health, Institute of Psychiatry and Neurology, Warsaw, Poland \\ A - Research concept and design, B - Collection and/or assembly of data, C - Data analysis and interpretation, \\ $D$ - Writing the article, E-Critical revision of the article, F-Final approval of article \\ Lisiecka-Biełanowicz M, Molenda B. Effectiveness of health-promoting activities in the area of general hearing screening tests in newborns \\ in Poland. Ann Agric Environ Med. 2019; 26(3): 445-449. doi: 10.26444/aaem/102691
}

\begin{abstract}
Introduction. An analysis of the impact of health promotion efforts as part of the Polish Universal Neonatal Hearing Screening Program demonstrated diagnostic efficacy. The health promotion efforts had been efficiently implemented via a proper execution of this long-term Program by the Great Orchestra for Christmas Charity (WOŚP) foundation.

Objective. The aim of the study was to demonstrate the impact of health promotion efforts by public benefit organizations by analyzing the WOŚP foundation's involvement in the Program in Poland during 2003-2015.

Materials and method. Statistical data for 2003-2015 were obtained from the database of the Department of Otolaryngology and Laryngeal Oncology at Poznan University of Medical Sciences. The analyzed data included the rates of hearingimpairment detection (phase 1), diagnosis (phase 2), and treatment (phase 3 ) in the newborns included in the Program, as well as the documentation of expenditures based on WOŚP's foundation annual financial reports.

Results. A total of 4,672,704 newborns were screened from 2003-2015, which amounted to approximately 360,000 screened patients per year. During the analyzed 12 years of the Program, the mean proportion of children who underwent screening was $96.1 \%$, with an observable, gradual increase in the number of children undergoing diagnostic assessments (phase 2) for a suspected hearing impairment, with the largest amount of money having been allocated to the Program implementation and expended in its early stages. The total cost of financing the Program by the year 2015 was 51,841,712 PLN.

Conclusions. The Polish Universal Neonatal Hearing Screening Program resulted in an improvement in the quality in the screening test, ensured more thorough diagnostics, and shortened the time needed to implement the appropriate treatment.
\end{abstract}

\section{Key words}

health care financing in Poland, Polish Universal Hearing Screening Program, The Great Orchestra for Christmas Charity (WOŚP) foundation

\section{INTRODUCTION}

In 2001, the Great Orchestra for Christmas Charity (WOŚP) foundation, a Polish public benefit organization, took an initiative to implement a Universal Newborn Hearing Screening Program (further referred to as the Program) in Poland [1]. The execution of this initiative is unique on a global scale, as no other country can boast a newborn hearing screening program covering such a large population of newborns within such a short period of time [2]. The distinctive feature of this Program is the implementation of crowdfunding, with a non-governmental organization being the principal source for its financing. Furthermore, the goals and execution of the Program are in line with the National Institutes of Health recommendations $[3,4]$ listed below:

- the purpose of screening tests is to detect mild, moderate, and severe hearing impairment;

- all newborns should be included in hearing screening;

- all newborns admitted to neonatal pathology units and those with risk factors for hearing impairment should be screened prior to discharge;

Address for correspondence: Bartłomiej Molenda, Department of Public Health, Institute of Psychiatry and Neurology in Warsaw

e-mail: bmolenda@ipin.edu.pl

Received: 29.10.2018; accepted: 08.01.2019; first published: 15.03.2019
- all infants should be screened within the first 3 months of life, with the optimal goal of conducting the screening prior to discharge from the hospital where they were born; - all hearing-impaired infants should be identified prior to 3 months of age, and treatment initiated by 6 months of age, as recommended by the Joint Committee on Infant Hearing;

- all hearing screening programs must include treatment intervention and rehabilitation solutions for children with detected hearing impairment.

Hearing impairment, which is detected on average in 3 out of 1,000 newborns $[5,6,7,8]$, should be dealt with within the healthcare system. If undetected in the early stages of a child's development, hearing impairment causes delayed speech and language skills, which may lead to cognitive challenges and pose learning problems during school education; it also disturbs the normal course of the child's development and poses many challenges for the child's parents and others.

The purpose of this study was to present the effects of efforts by non-governmental organizations, as illustrated by the example of the WOSP foundation, as part of the Universal Newborn Hearing Screening Program on the Polish healthcare system. 
The Program implements the goals of Polish healthcare policy, which includes minimizing abnormalities in children's physiological and functional parameters, as well as the associated discomfort and level of disability via preventive measures and early detection [9]. In general, health-oriented programs fall under the purview of the Polish Ministry of Health, which is responsible for their financing and implementation, as well as playing a coordinating role [10]. In the case of the Program presented here, all these responsibilities were taken over by the non-governmental organization WOŚP.

The nature of the Program is consistent with Polish health care system goals $[11,12]$, which include disease prevention, diagnosis, and treatment (and/or rehabilitation). Since it became operational in 2003, the Program has offered universal access to hearing screening tests in newborns. The Program's premise is also consistent with the Polish National Health Program's policy, which since 1990 has been focused on preventive measures [13]. These measures of disease prevention were to be implemented on each of the three types of health care services (i.e. primary, secondary [or specialist], and tertiary [or highly specialist] care) and stem the growing incidence of hearing impairment. The efficient coordination and rapid implementation of the Program by WOŚP helped reduce the differences in accessibility of health care services offering neonatal hearing screening all over Poland at the same time [14].

\section{HISTORY OF NEONATAL HEARING SCREENING IN POLAND}

The first hearing assessments conducted in a large population of newborns in Poland took place in 1992-1994 and were supervised by Prof. Maria Góralówna. Starting from 1995, Prof. Henryk Skarżyński implemented a grant offered by the Minister of Health for "the development of a uniform screening program for hearing deficits in newborns". In 19982001, hearing screening was advocated and implemented as part of a government program for disabled individuals and their community integration, financed by the Polish National Fund for the Rehabilitation of Individuals with Disabilities. This hearing screening program was carried out in several dozen centers in Poland [15]. During that period, diagnostic, treatment, and rehabilitation facilities were developed for the purpose of future screening programs. The Institute of Physiology and Pathology of Hearing coordinated hearing screening tests, which were conducted in 70 centers throughout Poland and included over 60,000 newborns [16]. The turn of the year 2000-2001 brought an opportunity to implement a program that would include the entire population of newborns nationwide. The turn of 2002-2003 sparked a decision to implement this program in all neonatal units. The program was called the Universal Neonatal Hearing Screening Program [Program Powszechnych Przesiewowych Badań Słuchu u Noworodków]. This was the first step in fully implementing the Program. The implementation of the Program to clinical practice in Poland was finalized as a result of an initiative by a non-governmental organization [1] Unlike earlier initiatives that gradually included individual centers, this project stipulated the inclusion into the Program a of all neonatal units at the same time [17].

\section{EXECUTION OF THE UNIVERSAL NEONATAL HEARING SCREENING PROGRAM BY THE GREAT ORCHESTRA OF CHRISTMAS CHARITY (WOŚP) FOUNDATION}

The WOŚP foundation provides socially beneficial, regulatorily defined public services, including providing health care and promoting health. These services are stipulated in the WOŚP statute and are meant to promote and improve children's health, as well as prevent diseases. WOŚP implements these goals by offering financial and in-kind support to the institutions and facilities with a corresponding operational scope [18].

Throughout its entire operation, WOŚP has collected a total of 121,477,219.01 USD and 432,370,735.37 PLN. The amount allocated for the Program in 2002-2015 exceeded $51,841,712.00$ PLN $[19,20]$. This amount also included some of the funds allocated for this purpose, from the previous, ninth annual crowd funding event organized by the Great Orchestra for Christmas Charity, which took place on 13 January 2001, and was dedicated mainly for neonatal and infant diagnostic purposes [21]. The largest amount of money was necessary to launch the Program. More specifically, to cover the cost of:

- personnel training courses for conducting hearing screening tests in newborns;

- purchasing medical equipment and other appliances for the purpose of the Program [22];

- administrative costs of the initiation and running of the Program;

- organizing the data transfer and collection [21];

- ensuring personal data protection of Program participants.

Analysis of Central Statistical Office data on all registered live births [16] in Poland, and the data collected at the Department of Otolaryngology and Laryngeal Oncology at the Poznan University of Medical Science, revealed that 96\% of Polish newborns were included in the Program.

Currently, a total of 505 medical centers take part in the Program by implementing the recommendations for early detection, diagnosis and intervention. There are 409 such units that provide level I care, 73 level II otolaryngologyaudiology centers, and 23 level III audiology-otolaryngology centers $[5,23]$.

\section{MATERIALS AND METHOD}

The study group was the population of neonates born in Poland in 2003-2015, inclusive. For the purpose of this study, the data collected in 2002 and 2016 were excluded from the analysis, as in neither of these cases did they span the full calendar year.

Data was collected according to the principles of the Program, whose purpose was to assess the hearing in every neonate born in Poland. Every newborn assessed in the hospital within the first 3 days of life was entered into a database. After undergoing hearing assessments conducted at level I and level II facilities, the children were classified into one of 4 groups:

- children with normal bilateral hearing and no risk factors for hearing loss;

- children with normal bilateral hearing and either prenatal or neonatal risk factors for hearing loss; 
- children with hearing impairment in at least one ear and no prenatal or neonatal risk factors for hearing loss,

- children with hearing impairment in at least one ear and either prenatal or neonatal risk factors for hearing loss;

Children with detected hearing impairment or those whose screening results were inconclusive were referred for an assessment at a level II facility in order to verify the findings and conduct thorough diagnostic assessments.

Moreover, the following data obtained from the Program's database were analyzed: the mean age (in days) of children referred to undergo phase II (i.e. diagnostic) assessments, and the mean age (in days) of children at the time the diagnostic phase was completed.

The data obtained for the individual years of the Program's operation were compared which helped in the evaluation of the efficiency of the Program in Poland during 2003-2015.

\section{RESULTS}

The presented results are based on information included in the Report of the Program Coordinator of 8 December 2016.

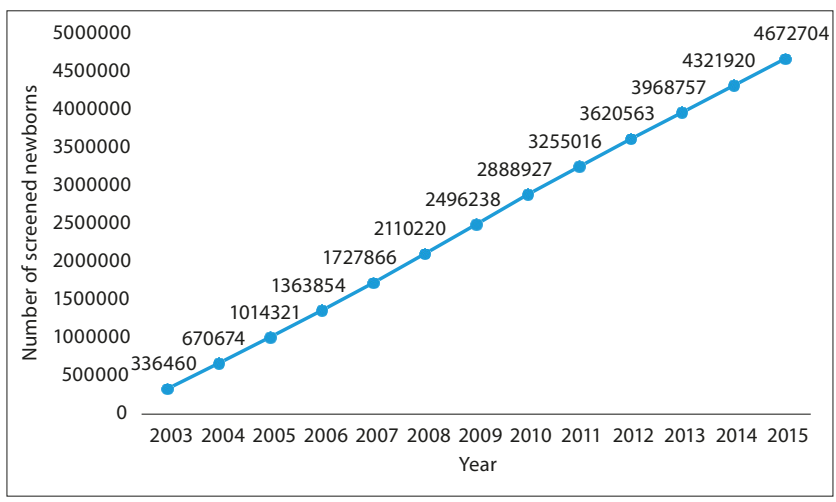

Figure 1. Cumulative number of neonates screened as part of the Program in Poland, 2003-2015.

Source: Presented data are based on the information from the Program's database

Since 2003, the mean annual increase in the number of screened newborns was 359,439 children. This number is closely associated with the number of live births [19]. The observed increase was steady, which means that the Program was being implemented efficiently and there was no "slump" in its execution throughout the analyzed period.

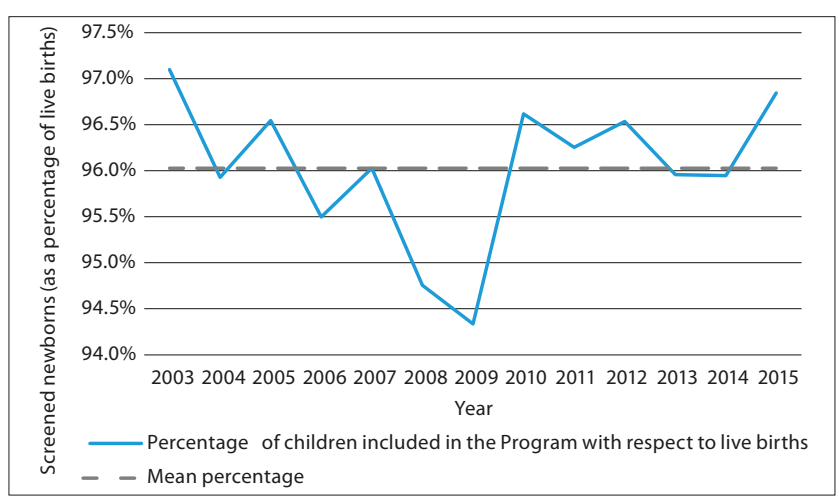

Figure 2. Proportion of neonates included in the Program with respect to live births, 2003-2015.

Source: Presented data are based on the information from the Program's database
The mean percentage of live newborns included in the Program during 2003-2015 was approximately 96.1\%. 2008 and 2009 saw a decrease (by 1.3 and 1.8 percentage points, respectively) in the proportion of screened newborns with respect to the 2003-2015 mean. This finding may be associated with the demographic surge observed in 2008-2009 (Fig. 3), and the limited organizational capabilities in diagnostic centers, including inadequate numbers of trained personnel.

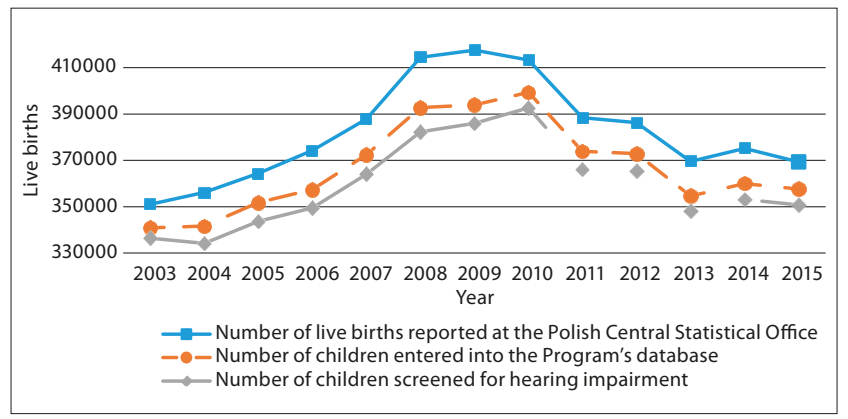

Figure 3. Relationship between the number of live births, children entered into the database, and children screened in Poland, 2003-2015.

Source: Presented data are based on the information from the Program's database

The number of children entered into the Program's database and screened for hearing impairment in the individual years was comparable to the respective number of live births [19]. The increase in the difference between the number of children included in the Program and the number or live births in the years 2008 and 2009 was associated with a demographic surge.

The number of newborns screened (phase 1) for hearing impairment was proportional to the number of children born in Poland in each of the evaluated years.

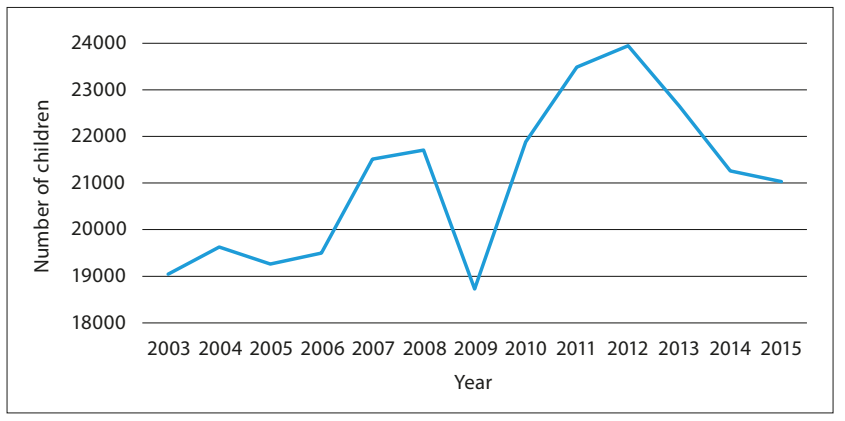

Figure 4. Number of children who completed their diagnostic assessments (phase 2) for detected hearing impairment in Poland, 2003-2015.

Source: Presented data are based on the information from the Program's database

From the Program's initiation, there was a perceptible rising tendency in the number of children who completed phase 2 diagnostic assessments (Fig. 4).

From 2003, there was a gradual and relatively steady decrease in the number of children who required intervention (phase 3) for their hearing impairment (Fig. 5).

Total cost of the Program until 2015, inclusive, was $51,841,712$ PLN [17]. A large proportion of the money was used at the beginning of the Program and was associated with preparations for its implementation. The amounts of money allocated for the Program in 2008, 2009 and 2011 were considerably higher than those allocated in the years 2002-2007 (Fig. 6). 


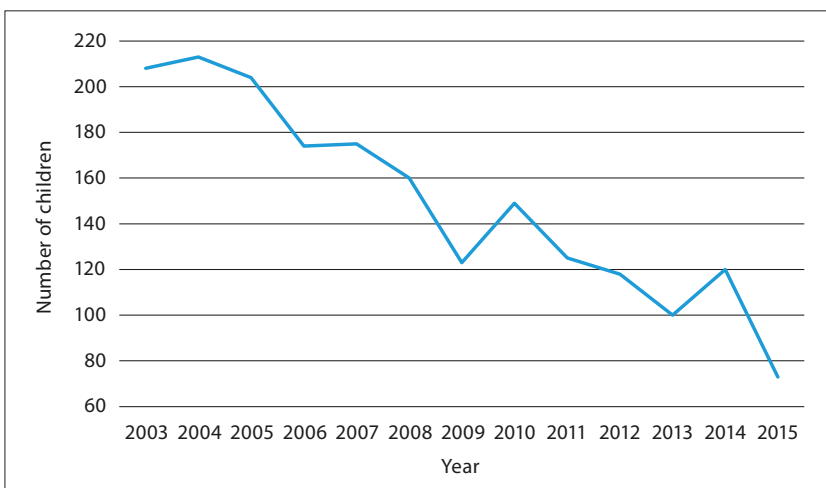

Figure 5. Number of children who qualified for phase 3 (intervention) in Poland, 2003-2015

Source: Presented data are based on the information from the Program's database

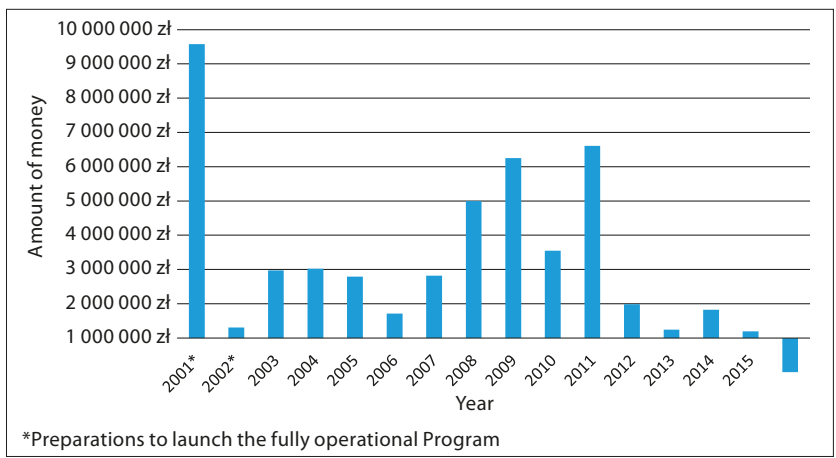

Figure 6. Amounts of money allocated by WOŚP for the purpose of the Program, 2001-2016.

Source: Presented data are based on the information from the Program's database

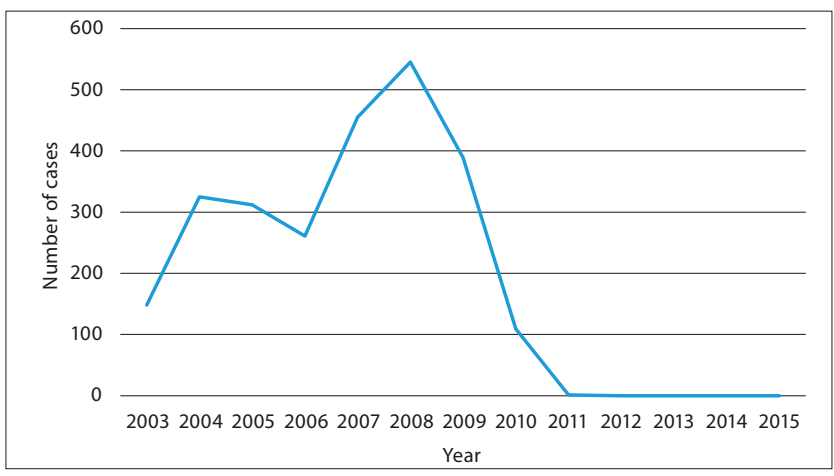

Figure 7. Number of cases where the type of hearing impairment was not recorded, 2003-2015.

Source: Presented data are based on the information from the Program's database

The number of cases where the type of hearing impairment was not recorded did not start to decrease noticeably until 2009. This may be associated with the fact that the funds allocated for equipment purchases and personnel training, which were the largest at the start of the Program and in the period 2007-2009, helped replace old diagnostic equipment with modern devices, and ensured an adequate level of personnel training in terms of new equipment use. Starting from 2011, the number of cases where the examining personnel was unable to determine the type of hearing impairment was zero (Fig. 7).

The recommended age (under 90 days) for the child to undergo stage-1 of diagnostic assessments was observed throughout the analyzed period (2003-2015). The mean age

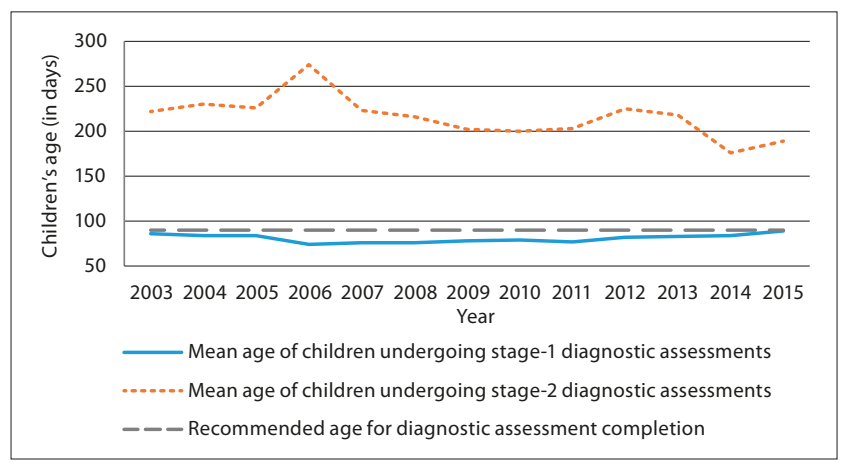

Figure 8. Mean age of children (in days) undergoing stage-1 and stage-2 diagnostic assessments (phase II) for hearing impairment, detected as part of the Program in Poland, 2003 - 2015.

Source: Presented data are based on the information from the Program's database

at which the children undergo stage-2 diagnostic assessments tended to decrease (Fig. 8).

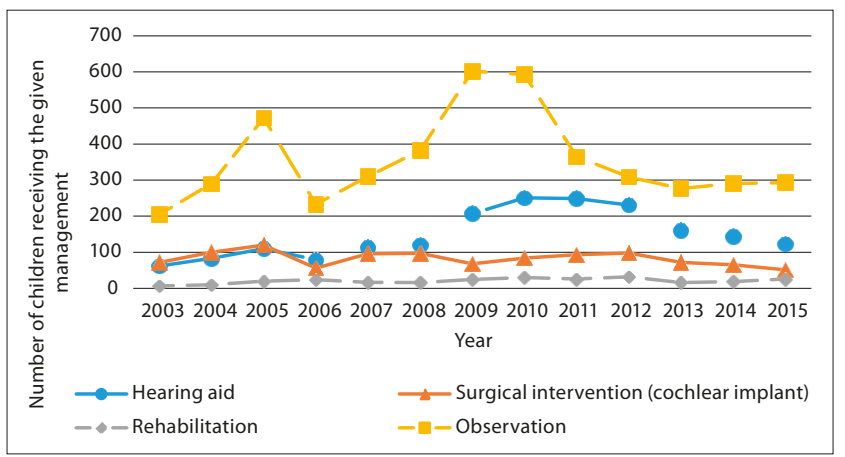

Figure 9. Types of management recommended at phase II of the Program in Poland, 2003-2015.

Source: Presented data are based on the information from the Program's database

Although the type of management most commonly recommended throughout the analyzed period was observation, the number of cases under observation decreased after 2010. This finding is related to the already mentioned decrease in the number of cases where the type of hearing impairment could not be determined.

The figures for surgical interventions and hearing aid use were similar in the years 2003-2008. Currently, the most common type of management (except observation) are hearing aids.

\section{DISCUSSION}

If it were not for the support of the WOŚP foundation, the introduction of a universal hearing screening program for Polish newborns, which had been planned by the Ministry of Health prior to 2001, would probably have been delayed or the Program would not have included the entire population of Polish-born neonates [7] In the latter case, the Program could not have been referred to as universal. In the former case, a multi-stage, prolonged introduction of the Program could have led to differences in the quality of hearing screening tests, not least due to an inadequate level of personnel training. Some centers could probably have afforded state-of-the-art medical equipment, while other centers would utilize older models. Such a scenario would preclude equal access to hearing screening tests for all Polish 
newborns. The model of running the Program adopted by the WOŚP foundation facilitated personnel training as well as streamlined modifying the Program over time. The Program is currently coordinated, overseen, and executed in medical centers of appropriate referral levels. Thus, it is much easier to maintain the desired test quality.

\section{CONCLUSIONS}

1) The proportion of newborns screened in Poland increased after 2002 due to the support afforded by WOŚP to the Universal Neonatal Hearing Screening Program. In the first year of the Program's operation, the number of newborns entered into the Program's database and screened for hearing impairment was 78,748. In the subsequent year, neonates born throughout Poland were included in the Program, with 336,460 newborns (i.e. $97 \%$ of all neonates born in Poland) entered into the Program's database. From then onward, 359,439 newborns on average were included in the Program each year, yielding a total of $4,672,704$ newborns screened during the evaluated 12 -year period.

2) The fact that the WOŚP foundation was responsible for executing the Program considerably relieved governmental organizations from the organizational and financial burden of conducting hearing screening in newborns, which reduced the Ministry of Health's expenditures for that purpose. The funds allocated by the WOŚP foundation were used to purchase medical equipment, cover personnel training costs, as well as maintain and update the Program's database. The greatest amount of money was allocated to the Program in the years 2001, 2008, 2009, and 2011, not least for the purpose of purchasing more modern medical equipment.

3) Long-term, comprehensive support of the Program's execution by the WOŚP foundation resulted in:

- increased numbers of correctly diagnosed children;

- opportunities to purchase new diagnostic equipment;

- continuous training of medical personnel.

This, in turn, ensured adequate screening test quality (i.e. obtaining reliable results) and more and more thorough diagnosis as part of the Program, which shortened the time to initiating the appropriate therapeutic management.

4) The number of medical facilities executing the Program across Poland increased from 440 in 2003 to 505 in 2015. This increase was mainly due to adding centers specializing in otolaryngology and audiology, i.e. level II and III medical facilities, responsible for conducting more indepth (stage-2) diagnostic assessments. The increase in the number of specialist centers also contributed to shortening the time of introduction of appropriate therapeutic management in children with hearing impairment.

\section{REFERENCES}

1. Radziszewska-Konopka M. Audiofonologia vol. XXI, Warszawa, 2002; p. 109-110 (in Polish).

2. Bolat H, Bebitoglu FG, Ozbas S, Altunsu AT, Kose MR. National newborn hearing screening program in Turkey: struggles and implementations between 2004 and 2008. Int J Pediatr Otorhinolaryngol. 2009 Dec; 73(12): 1621-3.

3. Ruben RJ. Early identification of hearing impairment in infants and young children. Inter J Pediatric Otorhinolaryngol. 1993.

4. Öztürk SEA, Aktaş S, Karakurt LT, Develioğlu ÖN, Murat Z, Çetinkaya F, Güleç SG. The follow-up results of newborn hearing screening of Gaziosmanpasa Taksim Research and Training Hospital. Turk Pediatri Ars. 2018 Mar 1; 53(1): 10-16.

5. Szyfter W, et al. Raport z realizacji Programu Powszechnych Przesiewowych Badań Słuchu Noworodków w Polsce w latach 2003-2015. http://www.owptp.pl/wp-content/uploads/2016/01/2016-02-03Raport-Roczny-PPPBSuN.pdf.

6. http://przesiew.imid.med.pl/faq.html\#ryzyko.

7. Firoozbakht M1, Mahmoudian S, Alaeddini F, Esmaeilzadeh M, Rafiei M, Firouzbakht A, Rahimi F, Farhadi M. Community-based newborn hearing screening programme for early detection of permanent hearing loss in Iran: an eight-year cross-sectional study from 2005 to 2012. J Med Screen. 2014 Mar; 21(1): 10-7.

8. Huang CM, Yang IY, Ma YC, Lin GS, Yang CC, Tsai HT, Lin HC. The effectiveness of the promotion of newborn hearing screening in Taiwan. Int J Pediatr Otorhinolaryngol. 2014 Jan; 78(1): 14-8.

9. Włodarczyk C, Współczesna Polityka Zdrowotna, wyd. II, Warszawa 2014; p. 51-53 (in Polish).

10. Ustawa z dnia 27 sierpnia 2004 r. o świadczeniach opieki zdrowotnej finansowanych ze środków publicznych p. 28-35 (in Polish).

11. Golinowska S (ed). Polska: Zarys systemu ochrony zdrowia, Warszawa 2012; p. 45-55.

12. Ministerstwo Zdrowia i Opieki Społecznej: Narodowy Program Zdrowia. Założenia Polityki Zdrowotnej Państwa. Warszawa, 1990 (in Polish).

13. Mueller-Malesiriska M, Skarżyński H, Ratyńska J, Ołtarzewski M, Szymborski J, Audiofonologia vol. XVIII, Warszawa, 2000; p. 30 (in Polish).

14. Skarżyński H. Audiofonologia vol. VIII, Warszawa, 1996; p. 8-9 (in Polish).

15. Radziszewska-Konopka M. Audiofonologia vol. XXI, Warszawa, 2002; p. 111-119 (in Polish)

16. Statut Fundacji „Wielka Orkiestra Świątecznej Pomocy” p. 2. (in Polish).

17. https://www.wosp.org.pl/fundacja/wazne/rozliczenia (in Polish).

18. materiały prasowe Instytut Fizjologii i Patologii Słuchu, Warszawa 2012 (in Polish).

19. GUS Roczniki demograficzne z lat 2003 - 2015 (in Polish).

20. Lin H-C, Shu M-T, Lee K-S, Lin H-Y, Lin G. Reducing false positives in newborn hearing screening program: How and why. Otology and Neurotolog 2007; 28(6): 788-792.

21. Ciorba A, Hatzopoulos S, Busi M, Guerrini P, Petruccelli J, Martini A. The universal newborn hearing screening program at the University Hospital of Ferrara: focus on costs and soft ware solutions. Int J Pediatr Otorhinolaryngol. 2008; 72(6): 807-16.

22. Krumm M, Syms MJ. Teleaudiology. Otolaryngol Clin North Am. 2011 Dec; 44(6): 1297-304.

23. Fundacja WOŚP, Biuletyn Uszko nr. 19 (in Polish).

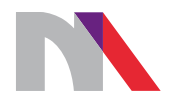

Ministry of Science and Higher Education

Republic of Poland

Generation of the DOI (Digital Object Identifier) - task financed under the agreement No. 618/P-DUN/2019 by the Minister of Science and Higher Education 